\title{
Synthesis of $\mathrm{Nb}_{2} \mathrm{O}_{5}$ Nanorods by a Soft Chemical Process
}

\author{
Haiyan Luo, ${ }^{1}$ Mingdeng Wei, ${ }^{1,2}$ and Kemei $W^{2}{ }^{2}$ \\ ${ }^{1}$ Institute of New Energy Technology and Nano-Materials, Fuzhou University, Fuzhou, Fujian 350002, China \\ ${ }^{2}$ National Engineering Research Center for Chemical Fertilizer Catalyst, Fuzhou University, Fuzhou, Fujian 350002, China
}

Correspondence should be addressed to Mingdeng Wei, wei-mingdeng@fzu.edu.cn

Received 14 July 2009; Accepted 19 October 2009

Recommended by Sang-Hee Cho

Single crystalline $\mathrm{Nb}_{2} \mathrm{O}_{5}$ nanorods have been successfully synthesized by a soft chemical process, in which only metal $\mathrm{Nb}$ powder and water were used as the starting materials. The synthesized $\mathrm{Nb}_{2} \mathrm{O}_{5}$ nanorods are highly crystalline and their growth is along [001] direction. The diameter of the nanorods is found to be ca. $50 \mathrm{~nm}$ and their lengths up to several micrometers. Based on the experimental results of XRD, SEM, and TEM measurements, the possible mechanism for the formation of $\mathrm{Nb}_{2} \mathrm{O}_{5}$ nanorods was discussed.

Copyright (C) 2009 Haiyan Luo et al. This is an open access article distributed under the Creative Commons Attribution License, which permits unrestricted use, distribution, and reproduction in any medium, provided the original work is properly cited.

\section{Introduction}

Since the discovery of carbon nanotubes in 1991 [1], onedimensional (1D) nanomaterials including nanorods, nanotubes, nanowires, nanofibers, nanobelts, and nanoribbons have attracted much attention due to their physical and chemical properties different from those of bulk materials [2]. In the past decades, a large number of $1 \mathrm{D}$ oxide nanomaterial have been synthesized, such as $\mathrm{TiO}_{2}[3], \mathrm{MnO}_{2}$ [4], $\mathrm{ZnO}$ [5], $\mathrm{SnO}_{2}$ [6], $\mathrm{VO}_{x}$ [7], $\mathrm{MoO}_{3}$ [8], $\mathrm{Ga}_{2} \mathrm{O}_{3}$ [9], $\mathrm{Ta}_{2} \mathrm{O}_{5}$ [10], $\mathrm{In}_{2} \mathrm{O}_{3}[11]$, and $\mathrm{Nb}_{2} \mathrm{O}_{5}$ [12]. Among them, $\mathrm{Nb}_{2} \mathrm{O}_{5}$ is an important semiconductor oxide with a wide band gap [13] and had been widely used in electrochromic devices [14], catalysts [15], chemical sensors [16], optical filters [17], solar cells [18], and lithium batteries [19]. As is well known, $\mathrm{Nb}_{2} \mathrm{O}_{5}$ has many polymorphic forms based on the octahedrally coordinated niobium atoms [20]. These polymorphs are identified with a variety of prefixes [21] such as $\mathrm{B}-\mathrm{Nb}_{2} \mathrm{O}_{5}\left(\mathrm{PdF}_{3}\right.$ rutile structure), $\mathrm{H}-\mathrm{Nb}_{2} \mathrm{O}_{5}\left(\mathrm{ReO}_{3}\right.$ type block, $3 \times 3$ or $3 \times 5$ octahedra), and $\mathrm{N}^{-\mathrm{Nb}_{2} \mathrm{O}_{5}}$ $\left(\mathrm{ReO}_{3}\right.$-type block, $4 \times 4$ octahedral). Among the niobium oxides, $\mathrm{Nb}_{2} \mathrm{O}_{5}$ is the most stable and exhibits the excellent chemical stability and corrosion resistance in both acid and base media [22]. So far, niobium oxide fibers have been prepared by using an electrospinning method [23]. Mozetič et al. [24] has synthesized $\mathrm{Nb}_{2} \mathrm{O}_{5}$ nanowires via a cold plasma treatment in the presence of a high neutral oxygen flux. Niobia-phase nanorods [25] were obtained by the hydrothermal treatment of a niobium peroxo complex precursor at $140^{\circ} \mathrm{C}$. Hu et al. [26] reported the synthesis of $\mathrm{Nb}_{2} \mathrm{O}_{5}$ nanocables using $\mathrm{NbCl}_{5}$ as a precursor. Kobayashi et al. [27] prepared $\mathrm{Nb}_{2} \mathrm{O}_{5}$ nanotubes using the layered $\mathrm{K}_{4} \mathrm{Nb}_{6} \mathrm{O}_{17}$ as a precursor, in which $\mathrm{K}_{4} \mathrm{Nb}_{6} \mathrm{O}_{17}$ was formed at over $1050^{\circ} \mathrm{C} . \mathrm{Nb}_{2} \mathrm{O}_{5}$ nanotubes have also been obtained using $\mathrm{HF}$ solution as a reactant [28]. Using amorphous $\mathrm{Nb}_{2} \mathrm{O}_{5} \cdot \mathrm{nH}_{2} \mathrm{O}$ as a precursor, $\mathrm{Nb}_{2} \mathrm{O}_{5}$ nanorods [29] were formed at a high temperature. More recently, $\mathrm{Nb}_{2} \mathrm{O}_{5}$ nanobelts were synthesized by using a hydrothermal route [30]. To the best of our knowledge, however, the synthesis of niobium oxide with 1D nanostructure has not been reported by using a soft chemical process. Here, we first fabricated $\mathrm{Nb}_{2} \mathrm{O}_{5}$ nanorods starting from metal $\mathrm{Nb}$ powder by a soft chemical process, without templates or catalysts, and using only the raw material and water. Furthermore, the possible mechanism for the formation of nanorods was discussed according to the experimental results.

\section{Experimental}

A soft chemical process was developed to prepare $\mathrm{Nb}_{2} \mathrm{O}_{5}$ nanorods. In a typical procedure, $0.1 \mathrm{~g}$ of the commercial metal $\mathrm{Nb}$ powder was dispersed into $40 \mathrm{~mL}$ distilled water and stirred, then transferred into a $50 \mathrm{~mL}$ Teflon-lined autoclave, and kept in an oven at $200^{\circ} \mathrm{C}$ for 3 to 30 days. The final products were washed with distilled water and then dried in the air. 


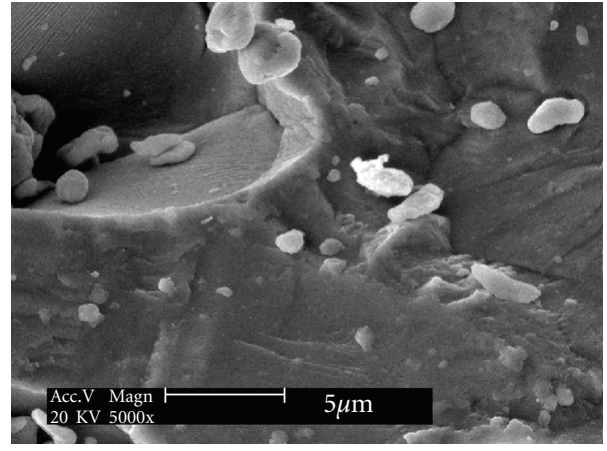

(a)

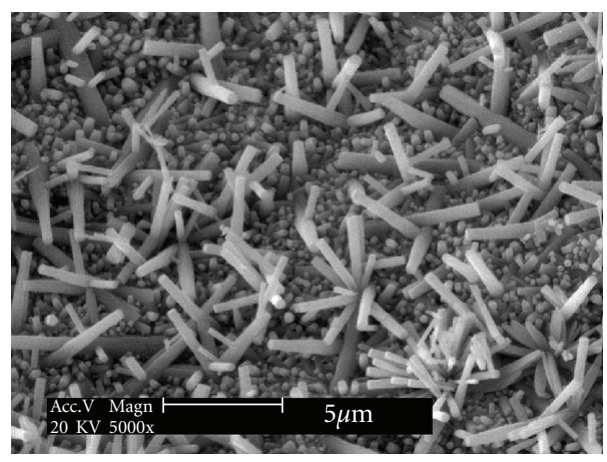

(c)

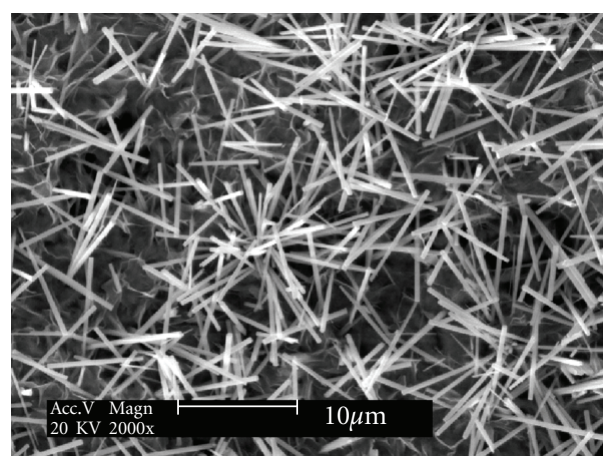

(e)

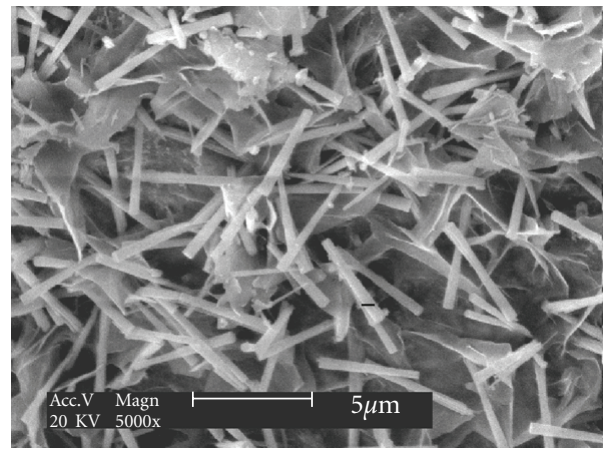

(b)

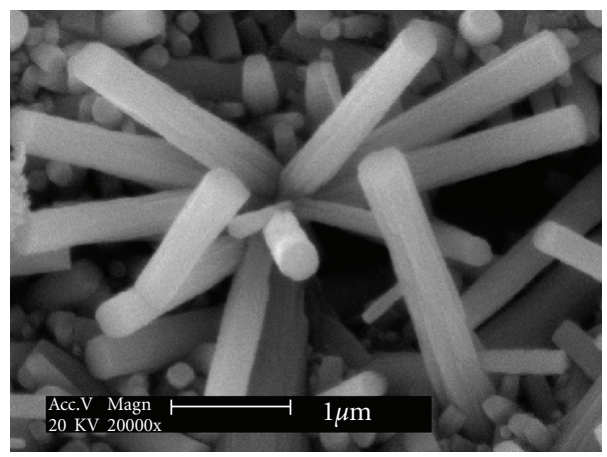

(d)

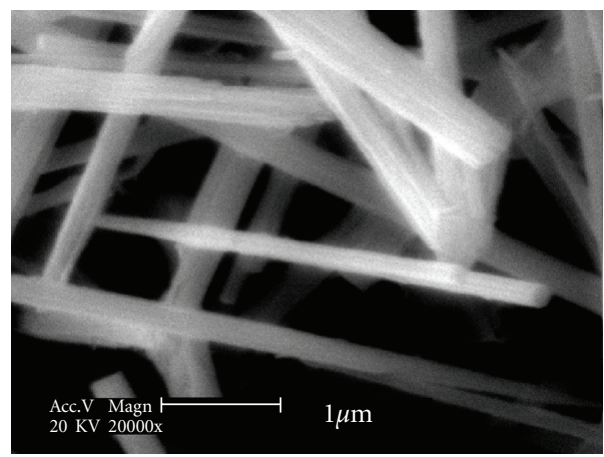

(f)

Figure 1: SEM images of (a) raw material $\mathrm{Nb}$ and the products synthesized at $200^{\circ} \mathrm{C}$ for different reaction times (b) 3, ((c), (d)) 15 , and ((e), (f)) 30 days.

Scanning electron (SEM) and transmission electron microscopy (TEM) were taken on a Philip-XL30 instrument and a JEOL 2010 instrument, respectively. X-ray diffraction (XRD) pattern was recorded on a PANalytical X'Pert spectrometer using the Co $\mathrm{K} \alpha$ radiation $(\lambda=1.78897 \AA)$ and the data would be changed to $\mathrm{Cu} \mathrm{K} \alpha$ data.

\section{Results and Discussion}

Figure 1 shows the SEM images of the raw $\mathrm{Nb}$ powder and the products obtained at $200^{\circ} \mathrm{C}$ for different reaction times. It clearly shows that the SEM morphology of the products is entirely different from the raw material $\mathrm{Nb}$ metal powder. Only particles with different sizes were detected in the raw material, as shown in Figure 1(a). After the raw $\mathrm{Nb}$ metal powder was treated in $\mathrm{H}_{2} \mathrm{O}$ at $200^{\circ} \mathrm{C}$ for 3 days, a large number of sheet-like and nanorod-like products were observed, as depicted in Figure 1(b). With increasing reaction time, numerous nanorods with a bundle-like structure were formed and the sheet-like products disappeared, as depicted in Figures 1(c)-1(f). It can also be found that the length of these nanorods increased significantly with reaction time. These nanorods lie close to each other and their lengths up to several micrometers.

The morphologies of the product can be further confirmed by TEM measurements. Figure 2(a) clearly shows a single nanorod obtained at $200^{\circ} \mathrm{C}$ for 30 days. The diameter of the nanorod is found to be ca. $50 \mathrm{~nm}$. Figure 2(b) is a highresolution TEM image and clearly reveals that the formed nanorods are single crystalline. The lattice fringes correspond 


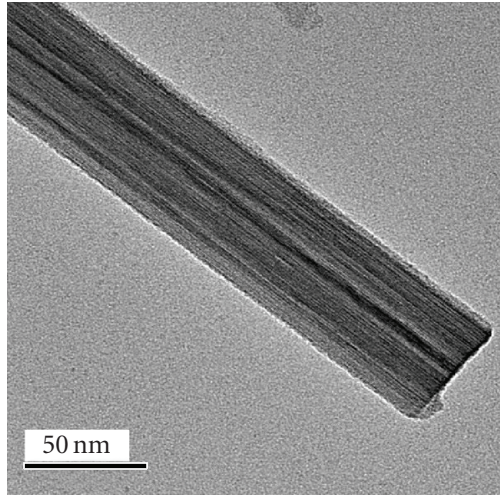

(a)

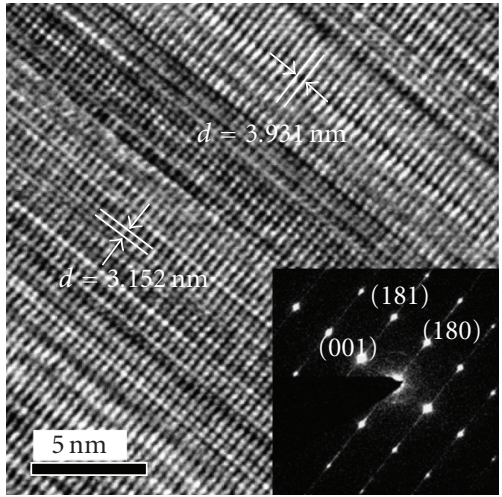

(b)

FIGURE 2: The TEM images of the product synthesized at $200^{\circ} \mathrm{C}$ for 30 days: (a) low magnification, and (b) high magnification (inset, SAED).

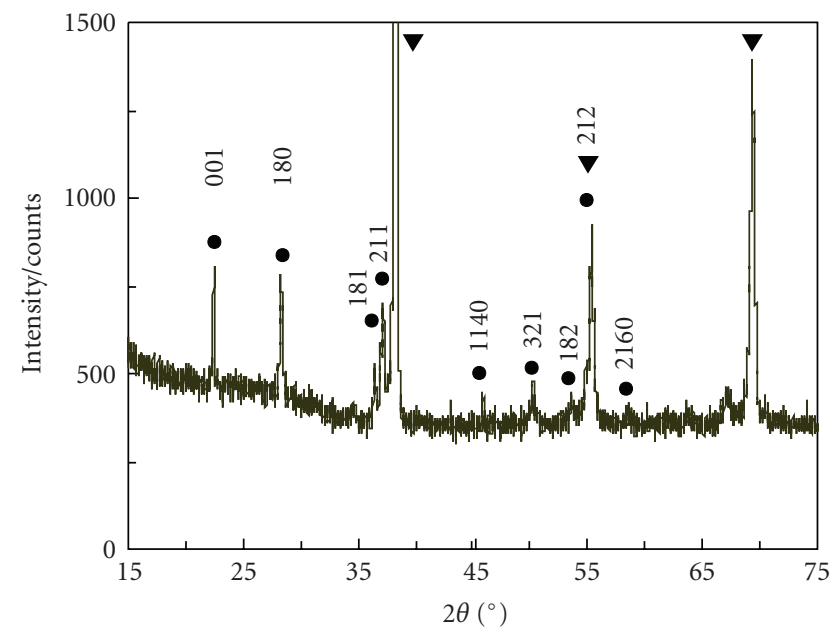

FIGURE 3: The XRD pattern of the product synthesized at $200^{\circ} \mathrm{C}$ for 30 days $\left(\bullet\right.$ : Orthorhombic $\mathrm{Nb}_{2} \mathrm{O}_{5},: \boldsymbol{\nabla}:$ Cubic $\left.\mathrm{Nb}\right)$.

to a $d$-pacing of 0.393 and $0.315 \mathrm{~nm}$, respectively. The typical selected area electron diffraction (SAED) taken from a single nanorod is shown in Figure 2b (inset). The pattern exhibits broadened and strong spots along the growth direction of the nanorods which can be attributed to the essentially asymmetric $1 \mathrm{D}$ nature of the long and thin nanorods. These results also indicate that the growth of nanorods is along [001] direction.

XRD measurement was used to identify the crystalline structure of the product, as shown in Figure 3. Besides raw $\mathrm{Nb}$ metal, the main phase detected was $\mathrm{Nb}_{2} \mathrm{O}_{5}$ which could be indexed to $\mathrm{Nb}_{2} \mathrm{O}_{5}$ (JPCDS 27-1313) with an orthorhombic structure. This result is in agreement with the TEM observations. Based on the experimental results of XRD, SEM, and TEM measurements, a possible model for the formation of $\mathrm{Nb}_{2} \mathrm{O}_{5}$ nanorods is suggested as follows: (i) the surface of the metal $\mathrm{Nb}$ powder was oxidized by oxygen in water under the hydrothermal conditions, and the sheetlike products were formed; (ii) the sheet-like products were splitted in order to release strong stress and lower the total energy, and then the nanorods were formed. Therefore, the formation of bundle-like structure can be contributed to the fact that the splitting of the sheets-like products is complete.

In the present work, metal $\mathrm{Nb}$ powder was used as a starting material and reacted with water under the hydrothermal conditions to yield single crystalline $\mathrm{Nb}_{2} \mathrm{O}_{5}$ nanorods. Although the purity of $\mathrm{Nb}_{2} \mathrm{O}_{5}$ nanorods in the final product is still to be improved, the synthetic route is very simple, in which templates or catalysts were not introduced into the reaction system. Comparing with the normal hydrothermal process, such a synthetic route took a long reaction time. This might be related to that the hydrothermal reaction was accelerated in the presence of templates or catalysts.

\section{Conclusions}

In summary, single crystalline $\mathrm{Nb}_{2} \mathrm{O}_{5}$ nanorods were successfully synthesized by a soft chemical process, in which the metal $\mathrm{Nb}$ powder and water were used as the precursors. The synthesized nanorods are highly crystalline and their growth direction is along [001]. The diameter of the nanorods is found to be ca. $50 \mathrm{~nm}$ and their lengths up to several micrometers. Furthermore, the work is underway to optimize the process and increase purity of nanorods in the product. Compared with other synthetic routes, no any catalysts or templates were introduced into the reaction system. We believe that the synthetic route of $\mathrm{Nb}_{2} \mathrm{O}_{5}$ nanorods from the metal $\mathrm{Nb}$ powder has the potential to prepare 1D nanostructural metal oxides.

\section{Acknowledgments}

This work was financially supported by the National High Technology Research and Development Program ("863") and Ministry of Education under Grant nos. 2007AA05Z438 and 200803860004, Science and Technology Program from Fujian Province (nos. 2008J0332, 2007HZ0005-1), and the startup funds from the Ministry of Education and Fuzhou University. 


\section{References}

[1] S. Iijima, "Helical microtubules of graphitic carbon," Nature, vol. 354, no. 6348, pp. 56-58, 1991.

[2] Y. Cui, Q. Wei, H. Park, and C. M. Lieber, "Nanowire nanosensors for highly sensitive and selective detection of biological and chemical species," Science, vol. 293, no. 5533, pp. 1289-1292, 2001.

[3] T. Kasuga, M. Hiramatsu, A. Hoson, T. Sekino, and K. Niihara, "Titania nanotubes prepared by chemical processing," Advanced Materials, vol. 11, no. 15, pp. 1307-1311, 1999.

[4] X. Wang and Y. Li, "Selected-control hydrothermal synthesis of $\alpha$ - and $\beta-\mathrm{MnO}_{2}$ single crystal nanowires," Journal of the American Chemical Society, vol. 124, no. 12, pp. 2880-2881, 2002.

[5] W. I. Park, J. S. Kim, G.-C. Yi, and H.-J. Lee, "ZnO nanorod logic circuits," Advanced Materials, vol. 17, no. 11, pp. 13931397, 2005.

[6] H. Huang, O. K. Tan, Y. C. Lee, M. S. Tse, J. Guo, and T. White, "In situ growth of $\mathrm{SnO}_{2}$ nanorods by plasma treatment of $\mathrm{SnO}_{2}$ thin films," Nanotechnology, vol. 17, no. 15, pp. 36683672, 2006.

[7] M. Wei, H. Sugihara, I. Honma, M. Ichihara, and H. Zhou, "A new metastable phase of crystallized $\mathrm{V}_{2} \mathrm{O}_{4} \cdot 0.25 \mathrm{H}_{2} \mathrm{O}$ nanowires: synthesis and electrochemical measurements," Advanced Materials, vol. 17, no. 24, pp. 2964-2969, 2005.

[8] H. Luo, M. Wei, and K. Wei, "A new metastable phase of crystallized $\mathrm{MoO}_{3} \cdot 0.3 \mathrm{H}_{2} \mathrm{O}$ nanobelts," Materials Chemistry and Physics, vol. 113, no. 1, pp. 85-90, 2009.

[9] J. Zhang, F. Jiang, Y. Yang, and J. Li, "Catalyst-assisted vaporliquid-solid growth of single-crystal $\mathrm{Ga}_{2} \mathrm{O}_{3}$ nanobelts," Journal of Physical Chemistry B, vol. 109, no. 27, pp. 13143-13147, 2005.

[10] H. A. El-Sayed and V. I. Birss, "Controlled interconversion of nanoarray of Ta dimples and high aspect ratio Ta oxide nanotubes," Nano Letters, vol. 9, no. 4, pp. 1350-1355, 2009.

[11] A. J. Chiquito, A. J. C. Lanfredi, R. F.M. de Oliveira, L. P. Pozzi, and E. R. Leite, "Electron dephasing and weak localization in $\mathrm{Sn}$ doped $\mathrm{In}_{2} \mathrm{O}_{3}$ nanowires," Nano Letters, vol. 7, no. 5, pp. 1439-1443, 2007.

[12] K. Sayama, H. Sugihara, and H. Arakawa, "Photoelectrochemical properties of a porous $\mathrm{Nb}_{2} \mathrm{O}_{5}$ electrode sensitized by a ruthenium dye," Chemistry of Materials, vol. 10, no. 12, pp. 3825-3832, 1998.

[13] K. Hara, T. Horiguchi, T. Kinoshita, K. Sayama, H. Sugihara, and H. Arakawa, "Highly efficient photon-to-electron conversion with mercurochrome-sensitized nanoporous oxide semiconductor solar cells," Solar Energy Materials and Solar Cells, vol. 64, no. 2, pp. 115-134, 2000.

[14] B. Varghese, S. C. Haur, and C.-T. Lim, " $\mathrm{Nb}_{2} \mathrm{O}_{5}$ nanowires as efficient electron field emitters," Journal of Physical Chemistry C, vol. 112, no. 27, pp. 10008-10012, 2008.

[15] K. Tanabe, "Catalytic application of niobium compounds," Catalysis Today, vol. 78, no. 1-4, pp. 65-77, 2003.

[16] M. E. Gimon-Kinsel and K. J. Balkus Jr., "Pulsed laser deposition of mesoporous niobium oxide thin films and application as chemical sensors," Microporous and Mesoporous Materials, vol. 28, no. 1, pp. 113-123, 1999.

[17] I. Sieber, H. Hildebrand, A. Friedrich, and P. Schmuki, "Formation of self-organized niobium porous oxide on niobium," Electrochemistry Communications, vol. 7, no. 1, pp. 97-100, 2005.
[18] R. Jose, V. Thavasi, and S. Ramakrishna, "Metal oxides for dyesensitized solar cells," Journal of the American Ceramic Society, vol. 92, no. 2, pp. 289-301, 2009.

[19] M. Wei, K. Wei, M. Ichihara, and H. Zhou, " $\mathrm{Nb}_{2} \mathrm{O}_{5}$ nanobelts: a lithium intercalation host with large capacity and high rate capability," Electrochemistry Communications, vol. 10, no. 7, pp. 980-983, 2008.

[20] A. F. Wells, Structural Inorganic Chemistry, Oxford Science, Oxford, UK, 5th edition, 1984.

[21] B. M. Gatehouse and A. D. Wadsley, "The crystal structure of the high temperature form of niobium pentoxide," Acta Crystallographica, vol. 17, no. 12, pp. 1545-1554, 1964.

[22] S. Venkataraj, R. Drese, Ch. Liesch, O. Kappertz, R. Jayavel, and M. Wuttig, "Temperature stability of sputtered niobiumoxide films," Journal of Applied Physics, vol. 91, no. 8, pp. 48634871, 2002.

[23] P. Viswanathamurthi, N. Bhattarai, H. Y. Kim, D. R. Lee, S. R. Kim, and M. A. Morris, "Preparation and morphology of niobium oxide fibres by electrospinning," Chemical Physics Letters, vol. 374, no. 1-2, pp. 79-84, 2003.

[24] M. Mozetič, U. Cvelbar, M. K. Sunkara, and S. Vaddiraju, "A method for the rapid synthesis of large quantities of metal oxide nanowires at low temperatures," Advanced Materials, vol. 17, no. 17, pp. 2138-2142, 2005.

[25] E. R. Leite, C. Vila, J. Bettini, and E. Longo, "Synthesis of niobia nanocrystals with controlled morphology," Journal of Physical Chemistry B, vol. 110, no. 37, pp. 18088-18090, 2006.

[26] W. Hu, Y. Zhao, Z. Liu, and Y. Zhu, " $\mathrm{NbS}_{2} / \mathrm{Nb}_{2} \mathrm{O}_{5}$ nanocables," Nanotechnology, vol. 18, no. 9, pp. 1-5, 2007.

[27] Y. Kobayashi, H. Hata, M. Salama, and T. E. Mallouk, "Scrolled sheet precursor route to niobium and tantalum oxide nanotubes," Nano Letters, vol. 7, no. 7, pp. 2142-2145, 2007.

[28] C. Yan and D. Xue, "Formation of $\mathrm{Nb}_{2} \mathrm{O}_{5}$ nanotube arrays through phase transformation," Advanced Materials, vol. 20, no. 5, pp. 1055-1058, 2008.

[29] Y. Zhou, Z. Qiu, M. Lü, A. Zhang, and Q. Ma, "Preparation and spectroscopic properties of $\mathrm{Nb}_{2} \mathrm{O}_{5}$ nanorods," Journal of Luminescence, vol. 128, no. 8, pp. 1369-1372, 2008.

[30] M. Wei, Z.-m. Qi, M. Ichihara, and H. Zhou, "Synthesis of single-crystal niobium pentoxide nanobelts," Acta Materialia, vol. 56, no. 11, pp. 2488-2494, 2008. 

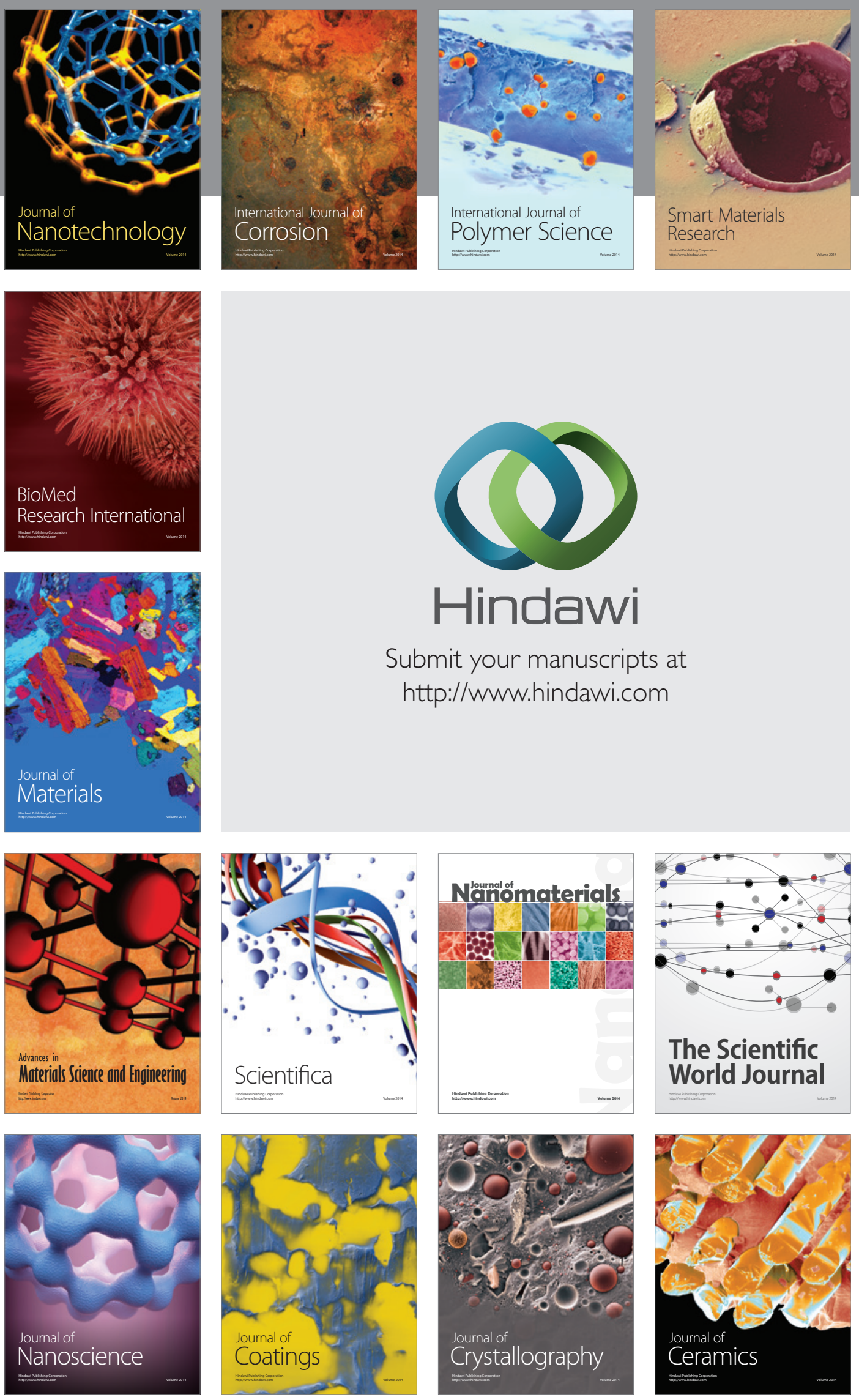

The Scientific World Journal

Submit your manuscripts at

http://www.hindawi.com

\section{World Journal}

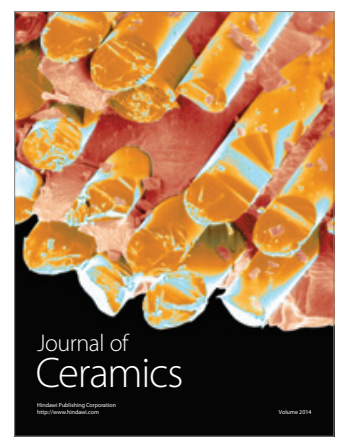

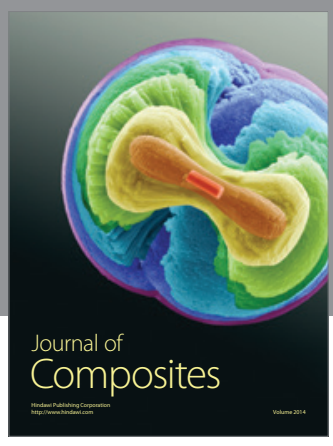
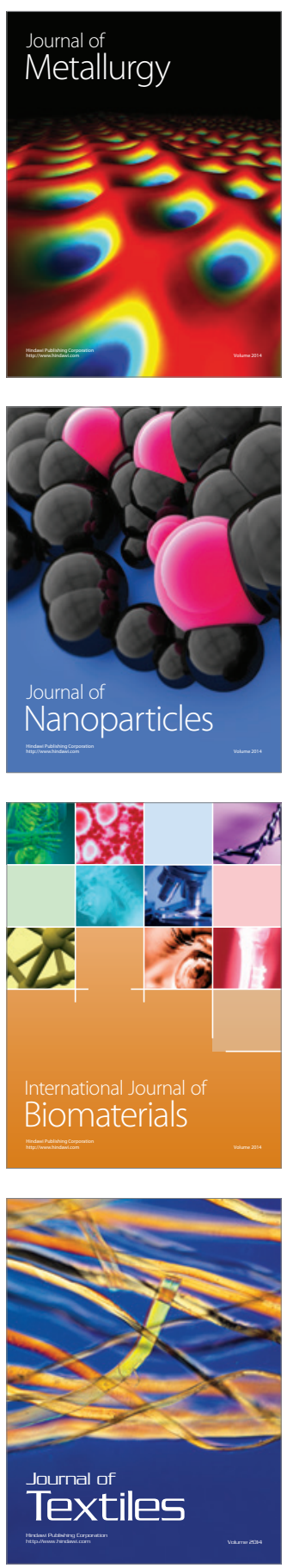